\title{
ANALISA PENERAPAN KEBIJAKAN FASILITAS KAWASAN BERIKAT PADA KANTOR PENGAWASAN DAN PELAYANAN BEA DAN CUKAI TIPE MADYA PABEAN A JAKARTA TIMUR
}

\author{
Ratiyah \\ Prodi Akuntansi, Universitas Bina Sarana Informatika, \\ ratiyah.rty@bsi.ac.id \\ Hartanti \\ Prodi Manajemen Pajak, Universitas Bina Sarana Informatika \\ hartanti.hti@bsi.ac.id \\ Yola Feranika \\ Prodi Manajemen Pajak, Universitas Bina Sarana Informatika \\ yolaferanika@bsi.ac.id
}

\begin{abstract}
The government continues to encourage export growth, apart from facilitating licensing and formulating supporting policies, the government also provides customs facilities in the form of bonded zone facilities. This Bonded Zone acts as an Export Processing Zone because goods produced in this area are prioritized for export. Government efforts to accelerate economic growth and increase the attractiveness of foreign and domestic investment. Based on Government Regulation Number 85 of 2015 concerning bonded storage is a building, place or area that meets certain requirements which is used to store imported goods and/or goods originating from other places in the customs area to be processed or combined before being exported or imported for use. The purpose of this research is to determine the implementation of the bonded zone facility policy provided by the Directorate General of Customs and Excise to bonded zone companies. This research is a qualitative research. The result of this research is that the Directorate General of Customs and Excise provides and implements a bonded zone facility policy and with the implementation of a bonded zone facility policy in order to facilitate the smooth flow of imported or exported documents and goods to entrepreneurs.
\end{abstract}

Keywords: Policy Implementation, Bonded Zone Facilities.

\begin{abstract}
ABSTRAK
Pemerintah terus mendorong pertumbuhan ekspor, selain dengan mempermudah perizinan dan membuat kebijakan pendukung pemerintah juga memberikan fasilitas kepabeanan berupa fasilitas kawasan berikat. Kawasan Berikat ini berperan sebagai Export Processing Zone karena barang-barang yang diproduksi dalam kawasan ini diutamakan untuk diekspor. Usaha pemerintah untuk menselarasikan pertumbuhan ekonomi dan meningkatkan daya tarik penanaman modal asing dan modal dalam negeri. Berdasarkan Peraturan Pemerintah Nomor 85 Tahun 2015 tentang penimbunan berikat adalah bangunan, tempat atau kawasan yang memenuhi persyaratan tertentu yang digunakan untuk menimbun barang impor dan/atau barang yang berasal dari tempat lain dalam daerah pabean guna diolah atau digabungkan sebelum diekspor atau diimpor untuk dipakai. Tujuan dilakukan penelitian ini adalah untuk mengetahui penerapan kebijakan fasilitas kawasan berikat yang diberikan oleh Direktorat Jenderal Bea Dan Cukai kepada perusahaan kawasan berikat. Penelitian ini merupakan penelitian kualitatif. Hasil dari penelitian ini adalah Direktorat Jenderal Bea Dan Cukai memberikan dan menerapkan kebijakan fasilitas kawasan berikat dan dengan adanya penerapan kebijakan fasilitas kawasan berikat guna memberikan kemudahan untuk memperlancar arus dokumen dan barang impor atau ekspor kepada pengusaha.
\end{abstract}

Kata Kunci: Penerepan Kebijakan, Fasilitas Kawasan Berikat 


\section{Pendahuluan}

Investasi merupakan suatu cara untuk meningkatkan kesejahteraan dimasa datang yang berguna untuk mengantisipasi adanya inflasi yang terjadi setiap tahunnya. Investasi juga dapat diartikan sebagai pembelian suatu aset dengan harapan bahwa aset tersebut akan menghasilkan keuntungan di masa akan datang. Dalam rangka meningkatkan investasi dan terutama untuk peningkatan ekspor, pemerintah memberikan insentif fiskal di bidang kepabeanan dan perpajakan di tempat penimbunan berikat kepada investor, salah satunya adalah Kawasan Berikat. Berdasarkan PP No. 32 tahun 2009 sebagaimana telah diubah dengan PP No. 85 tahun 2015 tentang tempat penimbunan berikat adalah bangunan, tempat, atau kawasan yang memenuhi persyaratan tertentu yang digunakan untuk menimbun barang impor dan/atau barang yang berasal dari tempat lain dalam daerah pabean guna diolah atau digabungkan, yang hasilnya terutama untuk diekspor dengan mendapatkan penangguhan Bea Masuk dan tidak dipungut Pajak Dalam Rangka Impor (PDRI).

Kawasan Berikat ini berperan sebagai Export Processing Zone karena barang-barang yang diproduksi dalam kawasan ini diutamakan untuk ekspor. Usaha pemerintah untuk menselarasikan pertumbuhan ekonomi dan meningkatkan daya tarik penanaman modal asing dan modal dalam negeri adalah melalui pemberian fasilitas berupa Kawasan Berikat. Dasar hukum untuk Kawasan Berikat adalah Undang-Undang No. 10 Tahun 1995 tentang kepabeanan yang sekarang diubah menjadi Undang-Undang No. 17 Tahun 2006. Perusahaan kawasan berikat mendapatkan penerimaan fasilitas yaitu penangguhan bea masuk, tidak dipungut pajak pertambahan nilai (PPN) dan pajak penghasilan atas barang mewah (PPnBM), serta PPh pasal 22. Adapun undang-undang yang mengatur tentang Kawasan Berikat salah satunya Peraturan Pemerintah No. 32 tahun 2009 dan diubah menjadi PP No. 85 tahun 2015 Peraturan Menteri Keuangan No.120/PMK.04/2013 sebagaimana telah diubah menjadi Peraturan Menteri Keuangan No.131/PMK.04/2018 dan Peraturan Dirjen Bea dan Cukai No. PER 17/BC/2012 sebagimana telah diubah menjadi Peraturan Dirjen Bea dan Cukai No. PER 19/BC/201.

Pengusaha di indonesia dituntut memiliki pengetahuan tentang prosedur ekspor dan impor berupa peraturan-peraturan, kepabeanan maupun perpajakan, hal tersebut dikarenakan proses keluar dan masuknya barang sangat cepat. Dalam hal ini peran pemerintah sangat penting terutama dalam memberikan kemudahan di bidang kepabeanan dan pajak bagi para pengusaha di indonesia dalam rangka meningkatkan daya saing ekspor di pasar internasional yang nantinya juga akan berpengaruh terhadap cash flow perusahaan.

\section{Permasalahan}

Permasalahan dalam penelitian ini adalah:

1. Bagaimana penerapan kebijakan fasilitas kawasan berikat pada KPPBC?

2. Apa saja fasilitas yang diberikan KKPBC kepada kawasan berikat?

\section{Tujuan}

\section{Tujuan dilakukan penelitian ini adalah:}

1. Untuk mengetahui bagaimana penerapan kebijakan fasilitas kawasan berikat pada KPPBC?

2. Untuk mengetahui apa saja fasilitas yang diberikan KKPBC kepada kawasan berikat?

\section{Tinjauan Pustaka}

A. Kawasan Berikat

\section{Pengertian Kawasan Berikat}

Widyastuti \& Sahara (2018) mengatakan bahwa "Kawasan Berikat adalah suatu bangunan, tempat atau kawasan dengan batasbatas tertentu yang di dalamnya melakukan kegiatan usaha industri pengolahan barang dan bahan, kegiatan rancang bangun perekatasaan, penyortiran, pemeriksaan awal, pemeriksaan akhir dan pengepakan atas barang dan bahan asal impor atau barang dan bahan dari dalam Daerah Pabean Indonesia lainnya yang hasilnya terutama untuk tujuan ekspor".

Menurut Permen No.131/PMK.04/2018, Kawasan berikat adalah tempat penimbunan berikat untuk menimbun barang impor dan/ atau barang yang berasal dari tempat lain dalam daerah pabean guna diolah atau digabungkan sebelum diekspor atau diimpor untuk dipakai.

\section{Aspek Kepabeanan}

Aspek yang terdapat dalam suatu organisasi didasarkan atas konsep dan filosofi dari suatu institut publik, seperti halnya dengan Direktorat Jenderal Bea dan Cukai. Purwito (2013:28) mengakatan bahwa aspek berkaitan erat dengan sumber daya manusia, moral dan digabungkan dengan tujuan organisasi kepabeanan yang bersifat universal dan terkait 
dengan konvensi internasional, perjanjian multirateral dan bilateral. Sesuai dengan jiwa perpajakan, aspek kepabeanan terdiri dari:

1. Aspek Keadilan

Pada aspek ini kewajiban kepabeanan hanya kepada anggota masyarakat yang melakukan kegiatan kepabeanan dan terhadap mereka diperlakukan sama dalam hal dan kondisi yang sama.

2. Pemberian Insentif

Terutama bagi investor dan produsen. Insentif tersebut misalnya Tempat Penimbunan Berikat (TPB), Gudang Berikat (GB) yang diberikan pembebasan dan atau keringanan atas impor mesin dan bahan baku dalam rangka ekspor dan pemberian persetujuan impor barang sebelum pelunasan bea masuk dilakukan.

3. Netralitas

Tidak ada diskriminasi dalam pelayanan kepabeanan dan dalam pemungutan bea masuk untuk menghindari distorsi yang dapat mengganggu perekonomian nasional.

4. Kelayakan Administrasi

Administrasi kepabeanan dilaksanakan secara tertib, terkendali, sederhana serta transparan. Tertib adminstrasi berdampak atas pengurangan penyimpanganpenyimpangan yang kemungkinan akan terjadi dan berisiko melalui peraturan yang jelas dan penegakan hukum.

\section{Tujuan Pembentukan Kawasan Berikat}

Menurut Purwito (2006:59), tujuan pembentukan kawasan berikat dibagi menjadi tiga, yaitu:

1. Meningkatkan efesien dengan mendekatkan persediaan bahan baku bagi industri, karena dalam kawasan tersebut terdapat suatu pusat distribusi yang akan mensuplai segala kebutuhan industri di dalamnya. Dengan cara ini, produsen tidak perlu lagi mengimpor dan mengurus customs clearance di pelabuhan bongkar atau menyewa tempat penimbunan lainnya.

2. Sarana pemberian fasilitas kepabeanan dan perpajakan, di dalam kawasan berikat atas barang-barang yang diimpor diberikan kemudahan berupa penangguhan, penundaan, keringanan atau pembebasan bea masuk dan pajak.

3. Meningkatkan daya saing produk ekspor di pasar global, karena biaya produksi menjadi jauh lebih murah dibandingkan dengan harga yang terjadi di pasar (actual price).

Untuk melaksanakan tujuan tersebut di atas, pemerintah memberikan kemudahankemudahan seperti:

a. Impor barang modal atau peralatan konstruksi/perluasan, peralatan kantor diberikan fasilitas penangguhan pembayaran Bea Masuk dan tidak dipungut PPN, PPnBM, dan PPh Pasal 22.

b. Barang atau bahan asal impor yang dimasukkan ke Kawasan Berikat diberikan fasilitas Penangguhan Bea Masuk, Pembebasan Bea Masuk, Cukai dan tidak dipungut PPN, PPnBM, PPh Pasal 22.

c. Atas penyerahan Barang Kena Pajak dalam negeri ke Kawasan Berikat diberikan fasilitas tidak dipungut PPN dan PPnBM.

d. Atas pemasukan Barang Kena Cukai yang berasal dari Daerah Pabean Indonesia Lainnya dibebaskan dari pengenaan cukai.

\section{Syarat Kawasan Berikat}

Purwito (2013:61) mengatakan bahwa "Suatu wilayah dapat menjadi kawasan berikat harus dapat memenuhi syarat-syarat khusus. Suatu wilayah pabean di Indonesia bisa ditetapkan sebagai wilayah kawasan berikat apabila sudah memenuhi syarat-syarat untuk menjadi kawasan berikat dan tidak semua kawasan industri bisa difungsikan sebagai kawasan berikat dan memperoleh segala fasilitas dalam kawasan berikat". Adapun syarat-syarat kawasan berikat:

1. Terdapat sarana dan prasana untuk dapat melakukan fungsi kawasan berikat.

2. Merupakan wilayah yang mempunyai batas tertentu dan jelas.

Memenuhi persyaratan perusahaan tertentu jenis perusahaan yang dapat diberikan izin PKB adalah perusahaan yang berbentuk:

a. Penanaman Modal Dalam Negeri (PMDN).

b. Penanaman Modal Asing (PMA), baik sebagian atau keseluruhan sahamnya.

c. Non-PMA atau PMDN dengan badan hukum Perseroan Terbatas (PT).

d. Koperasi yang memiliki badan hukum.

e. Yayasan.

Perusahaan yang memenuhi syarat PKB

Untuk bisa mendapatkan izin PKB, suatu perusahaan harus memenuhi beberapa ketentuan, antara lain:

1. Ada di dalam kawasan industri.

2. Jika berada dalam daerah yang tidak memiliki kawasan industri, maka 
perusahaan tersebut beralokasi di kawasan yang diperlukan sebagai kawasan industri. Penentuannya merupakan kewenangan Pemerintah Daerah Tingkat II (Kabupaten/Kotamadya).

3. Telah memiliki kawasan industri sebelum ketentuan mengenai kawasan berikat disahkan.

Menurut Permen No.131/PMK.04/2018, Persayaratan bagi Perusahaan yang bermaksud menjadi penyelenggara Kawasan berikat adalah:

a. Harus memiliki nomor induk berusaha

b. Memiliki izin usaha perdagangan, izin usaha pengolahan Kawasan, izin usaha industri, atau izin lain yang berkaitan dengan penyelenggaraan Kawasan.

c. Memiliki hasil konfirmasi status pajak sesuai dengan aplikasi yang menunjukkan valid.

d. Memiliki bukti kepemilikan atau penguasaan suatu Kawasan, tempat, atau bangunan yang mempunyai batas-batas yang jelas berikut peta lokasi/tempat dan rencana tata letak/denah yang akan dijadikan Kawasan berikat.

e. Telah dikukuhkan sebagai pengusaha kena pajak dan telah menyampaikan surat pemberitahuan tahunan pajak penghasilan tahun pajak terakhir sesuai dengan kewajibannya.

\section{B. Kebijakan Kasawan Berikat \\ 1. Penyelenggara Kawasan Berikat}

Menurut Permen No.131/PMK.04/2018,

Penyelenggara Kawasan berikat adalah badan hukum yang melakukan kegiatan menyediakan dan mengolah Kawasan untuk kegiatan pengusahaan Kawasan berikat.

Purwito (2006) mengatakan bahwa "Suatu kawasan berikat identik dengan terdapatnya industri-industri yang berlokasi di dalamnya. Dalam kawasan berikat ini, pengolahan industri dapat diselenggarakan oleh berbagai jenis perusahaan dengan segala jenis barang. Barang-barang yang dapat dimasukkan, diterima atau disimpan di dalam kawasan berikat juga diatur dengan ketentuan khusus". Adapun ketentuan khusus mengenai jenis barang dalam kawasan berikat tersebut, meliputi:

1. Barang yang berasal dari luar daerah Pabean Indonesia.
Barang yang berasal dari luar daerah pabean Indonesia, diatur dengan ketentuan:

a.Tanpa terlebih dahulu dikenakan pungutan bea cukai dan/atau pungutan negara lain hingga barang tersebut dikeluarkan dengan tujuan impor ke daerah pabeanan Indonesia lainnya.

b. Tanpa dikenakan pungutan bea cukai dan/atau pungutan negara lainnya apabila barang tersebut dikeluarkan dengan tujuan re-ekspor tanpa diolah.

c. Tanpa dikenakan pungutan bea cukai dan/atau pungutan negara lainnya jika barang tersebut dikeluarkan dengan tujuan ekspor setelah diolah dalam kawasan berikat.

2. Barang yang berasal dari daerah Pabean Indonesia.

Barang-barang yang berasal dari daerah pabean Indonesia lainnya tanpa terlebih dahulu dikenakan pungutan bea cukai dan/atau pungutan negara lain hingga barang-barang tersebut dikeluarkan dari kawasan berikat.

a. Barang-barang yang dimasukkan dalam kawasan berikat tidak dikenakan pungutan tata niaga impor.

b. Barang-barang yang asalnya dari luar negeri dapat dikeluarkan dari kawasan berikat untuk tujuan ke luar daerah pabean Indonesia atau re-ekspor tanpa harus dikenakan bea cukai dan/atau pungutan negara lainnya.

\section{Fasilitas Kepabeanan Kawasan Berikat}

Menurut Permen No.131/PMK.04/2018, berdasarkan manajemen risiko, terhadap Kawasan Berikat dapat diberikan fasilitas di bidang kepabeanan dan cukai, yaitu:

a. Pelayanan perizinan

b. Pelayanan kegiatan operasional.

\section{Lokasi Kawasan Berikat}

Menurut Permen No.131/PMK.04/2018, Kawasan Berikat harus berlokasi di:

a. Kawasan industri

b. Kawasan budidaya sesuai dengan rencana tata ruang wilayah yang ditetapkan.

Bangunan, tempat dan kawasan yang akan dijadikan sebagai Kawasan Berikat harus memenuhi persyaratan sebagai berikut:

a. Terletak di lokasi yang dapat langsung dimasuki dari jalan umum dan dapat dilalui oleh kendaraan pengangkut peti kemas 
dan/atau sarana pengangkut peti kemas lainya di air.

b. Mempunyai batas-batas yang jelas berupa pembatas alam atau pembatas buatan berupa pagar pemisah, dengan bangunan, tempat, atau kawasan lain, dan

c. Digunakan untuk melakukan kegiatan industri pengolahan bahan baku menjadi hasil produksi.

Penetapan tempat sebagai Kawasan Berikat dan pemberian ijin pengusaha Kawasan Berikat ditetapkan oleh Kepala Kantor Wilayah atau Kepala Kantor Pelayanan Utama atas nama Menteri.

\section{Kebijakan Kepabean}

Menurut Permen No.131/PMK.04/2018, Fasilitas bagi barang yang berasal dari luar pabean yang dimasukkan dari tempat penimbunan berikat, Kawasan bebas, Kawasan ekonomi khusus, atau Kawasan ekonomi lainnya yang ditetapkan oleh pemerintah ke Kawasan Berikat adalah:

a. Diberikan penangguhan bea masuk

b. Diberikan pembebasan cukai

c. Tidak dipungut PDRI

d. Tidak dipungut PPN atau PPnBM

\section{Hasil Penelitian Terdahulu}

Hasil penelitian dari Ratna Yunita (2013) menunjukan bahwa pengawasan kebijakan fasilitas kawasan berikat pada PT.XYZ sudah berjalan sesuai dengan peraturan perundang-undangan yang berlaku. Dalam pelaksanaanya terjadi kendala yang bersifat internal, seperti kurangnya koordinasi antar bagian di PT.XYZ, maupun kendala yang bersifat eksternal, seperti kurangnya jumlah SDM yang dimiliki pihak Bea dan Cukai, kurangnya integritas petugas Bea dan Cukai dan belum dibangunya sistem teknologi dan informasi yang terpusat.

Prasetyo dwi nugroho, Ratnawati kurnia Jurnal Universitas presiden, akutansi 2018 Pengaruh Orientasi Pasar dan Penghindaran Pajak terhadap Penyalahgunaan Fasilitas Pajak oleh Pengusaha Dalam Kawasan Berikat (PDKB) yang Terdaftar di Kantor Pengawasan dan Pelayanan Bea dan Cukai (KPPBC) Tipe Madya Pabean. 1. orientasi pasar berpengaruh negatif secara signifikan terhadap penyalahgunaan fasilitas pajak yang dilakukan oleh Pengusaha Dalam Kawasan Berikat 2. penghindaran pajak berpengaruh positif secara signifikan terhadap penyalahgunaan fasilitas pajak yang dilakukan oleh Pengusaha Dalam Kawasan Berikat (PDKB).

Deby Valentina Jurnal Manajemen Universitas Tarumanagara,2018 Analisis pengawasan serta pengaruh kawasan berikat terhadap arus kas,beban pajak dan aktifitas ekspor.

fasilitas kawasan berikat pada PT. XYZ masih layak diimplementasikan terhadap kegiatan ekspor- impor perusahaan dengan menganalisa manfaat yang diterima dari segi perpajakan.

Olgi risnanda Jurnal UIN SUSKA riau Akuntansi ,2019 'Prosedur Pengeluaran Barang impor terhadapPenangguhan Bea Masuk melalui Kawasan Berikat di Kantor Pengawasandan Pelayanan Bea Cukai (KPPBC) Tipe Madya Pabean B Pekanbaru. Penelitian ini dilakukan dilokasi obyek penelitian yaitu pada KantorPengawasan dan Pelayanan Bea Cukai Tipe Madya Pabean B Pekanbaru.

\section{Metode Penelitian}

Penelitian ini adalah penelitian kualitatif, dimana sumber data diperoleh dengan melakukan observasi dan wawancara yang terkait dengan penerapan kebijakan kawasan berikat di bagian PKC IV Kantor Pengawasan Dan Pelayanan Bea Dan Cukai Tipe Madya Pabean A Jakarta Timur. Dan teknik analisis data yang akan digunakan dalam penelitian ini menggunakan metode analisis deskriptif kualitatif, yaitu dengan menganalisis dan mendeskripsikan data yang diperoleh.

\section{Hasil Dan Pembahasan}

\section{A. Analisa Penerapan Kebijakan Fasilitas KB pada KPPBC}

Pemerintah telah menetapkan berbagai fasilitas di kawasan berikat sebagai upaya mendukung upaya ekspor ke luar negeri yang lebih tinggi. Di dalam kawasan ini, ada ketentuan khusus di bidang kepabeanan yang diberlakukan misalnya pemasukan barang luar daerah pabean tidak terkena pengutan bea masuk.

\section{B. Penerapan kebijakan fasilitas Kawasan Berikat antara lain:}

Penerapan kebijakan fasilitas bagi perusahaan Kawasan berikat adalah:

1. Diberikan penangguhan bea masuk.

2. Diberikan pembebasan cukai dan/atau.

3. Tidak dipungut pajak dalam rangka impor (PPN, PPh 22, dan PPnBM).

Tabel 1 
Account: Vol 8 No 2 Ratiyah. Hartanti. Yola Feranika

\begin{tabular}{|c|c|}
\hline \multirow{2}{*}{\multicolumn{2}{|c|}{$\begin{array}{l}\text { Perlakuan Kepabeanan, Cukai dan Perpajakan } \\
\begin{array}{|l}\text { Pemasukan } \\
\end{array}\end{array}$}} \\
\hline & \\
\hline Kawasan Berikat & $\begin{array}{l}\text { Tempat Luar Dalam Daerah } \\
\text { Pabean (TLDDP) }\end{array}$ \\
\hline $\begin{array}{l}\text { Penangguhan } \text { Bea } \\
\text { Masuk, Pembebasan Cukai } \\
\text { dan/atau Tidak dipungut } \\
\text { PDRI (PPN, PPh } 21 \text { dan } \\
\text { PPnBM) }\end{array}$ & $\begin{array}{l}\text { Melunasi Bea Masuk, Cukai } \\
\text { dan PDRI (diimpor untuk } \\
\text { dipakai) }\end{array}$ \\
\hline & $\begin{array}{l}\text { Penangguhan atau } \\
\text { pembebasan Bea Masuk dan } \\
\text { Cukai (barang ditunjukan } \\
\text { kepaada subjek penerimaan } \\
\text { fasilitas penangguhan atau } \\
\text { pembebasan Bea Masuk dan } \\
\text { Cukai) }\end{array}$ \\
\hline
\end{tabular}

\begin{tabular}{|c|c|}
\hline \multicolumn{2}{|l|}{ Pengeluaran } \\
\hline Kawasan Berikat & $\begin{array}{l}\text { Tempat Luar Dalam Daerah } \\
\text { Pabean (TLDDP) }\end{array}$ \\
\hline $\begin{array}{l}\text { Pembebasan cukai } \\
\text { dan/atau tidak dipungut PPN } \\
\text { atau PPnBM }\end{array}$ & \begin{tabular}{l}
\multicolumn{3}{c}{ Melunasi PPN atau } \\
PPnBM yang pada saat \\
pemasukannya \\
dipungut (penyerahan BKP)
\end{tabular} \\
\hline & $\begin{array}{c}\text { Tidak dipungut PPN } \\
\text { (penyerahan non BKP) }\end{array}$ \\
\hline & $\begin{array}{lll} & \text { Tidak dikenai PPN } \\
\text { atau PPnBM } & \text { (bukan } \\
\text { penyerahan) } & \end{array}$ \\
\hline
\end{tabular}

Berdasarkan tabel 1 diketahui bahwa penerapan kebijakan dan pemberian fasilitas kepabeanan oleh Direktorat Jenderal Bea dan Cukai memperlancar arus dokumen dan barang impor atau ekspor kepada pengusaha, sehingga pengusaha dapat menjalankan usahanya tanpa hambatan dan memperlancar cash flow dari perusahaan. Pemberian fasilitas kawasan berikat ini diberikan kepada pengusaha yang telah memenuhi serangkaian prosedur dan persyaratan tertentu yang telah diatur dalam Undang-Undang..

Dasar Hukum Tentang Kawasan Berikat:

1. Peraturan Pemerintah No. 32 tahun 2009 dan diubah menjadi PP No. 85 tahun 2015

2. Peraturan Menteri Keungan No.120/PMK.04/2013 sebagaimana telah diubah menjadi Peraturan Menteri Keuangan No.131/PMK.04/2018

3. Peraturan Dirjen Bea dan Cukai No. PER 17/BC/2012 sebagimana telah diubah menjadi Peraturan Dirjen Bea dan Cukai No. PER 19/BC/2013.

Kendala yang pernah dihadapi pada saat DJBC menerapkan kebijakan fasilitas kawasan berikat adalah kurangnya persyaratan izin pemberian penyelenggaraan izin kawasan berikat berupa syarat fisik dan syarat administrasi yang menyebabkan izin prmberian fasilitas kawasan berikat tidak bisa langsung diberikan. Dan kendala lainnya karena kebijakan ini berpotensi untuk disalahgunakan perlunya pengawasan oleh petugas Bea Cukai untuk itu DJBC secara khusus memerintahkan petugasnya untuk pengawasi kawasan berikat. Petugas tersebut kepada Hanggar yang memiliki serangkaian kewenangan dan kewajiban yang harus dilaksanakan.

\section{Fasilitas Yang diberikan KPPBC pada Kawasan Berikat}

Direktorat Jenderal Bea dan Cukai mempunyai kegiatan utama terhadap Perusahaan Kawasan Berikat salah satunya dengan memberikan beberapa penerapan kebijakan fasilitas kawasan berikat, adapun fasilitas yang diberikan sebagai berikut:

1. Penangguhan Bea Masuk

Bea Masuk yaitu pengutan negara berdasarkan Undang-Undang Kepabeanan yang dikenakan terhadap barang yang diimpor. Yang termasuk mendapatkan penangguhan Bea Masuk yaitu Tempat Penimbunan Berikat (TPB) seperti bangunan, tempat, atau kawasan yang memenuhi persyaratan tertentu yang digunakan untuk menimbun, mengolah, memamerkan atau menyediakan barang untuk dijual. Jika barang masuk dari luar kedalam daerah Pabean maka akan tidak dikenakan bea masuk.

2. Pembebasan Cukai

Cukai yaitu pengutan negara yang dikenakan terhadap barang-barang tertentu yang mempunyai sifat atau karakteristik yang ditetapkan dalam Undang-Undang Cukai. Yang dimaksud pembebasan cukai yaitu barang seperti ethanol, alcohol, rokok dan lain-lain jika dipergunakan untuk penelitian atau untuk mengetahui komposisi yang ada maka akan terjadi pembebasan cukai. Namun jika barang tersebut digunakan untuk dijual atau dipakai pribadi maka tidak ada pembebasan cukai dan tetap dikenakan pajak impor.

3. Pajak Dalam Rangka Impor (PPN, PPh 22, PPnBM)

Pajak Dalam Rangka Impor (PPN, PPh 22, PPnBM) yaitu pajak yang dikenakan berdasarkan Undang-Undang No. 42 Tahun 
2000 atas perubahan ketiga dari UndangUndang No. 8 Tahun 1983 tentang PPN, $\mathrm{PPh} 22$, PPnBM. Untuk barang luar yang masuk ke Kawasan Berikat akan dikenakan biaya impor sesuai tarif yang diberlakukan dan yang ditentukan sesuai dengan yang telah ditetapkan. Untuk barang yang masuk ke Kawasan Berikat sebagai penelitian atau sebagai tujuan lain yang bermanfaat maka tidak dikenakan PPn, PPh21, dan PPnBM.

Disamping itu adapun kemudahan bagi kawasan berikat yang mendapat fasilitas diantaranya:

1. Barang modal yang berupa mesin asal impor apabila telah melampaui jangka waktu dua tahun sejak pengimporan atau sejak menjadi aset perusahaan dapat dipindahtangankan dengan tanpa kewajiban membayar Bea Masuk yang terutang.

2. Pengusaha Di Kawasan Berikat (PDKB) yang termaksud dalam Daftar Putih dapat mempertaruhkan jaminan berupa Surat Sanggup Bayar (SSB) kepada KPPBC yang bersangkutan atas pemasukan dan pengeluaran barang ke PDKB yang dipersyaratkan untuk mempertaruhkan jaminan.

D. Adapun keuntungan manfaat bagi perusahaan kawasan berikat yang diberikan KPPBC antara lain:

1. Efisien waktu pengiriman barang dengan tidak dilakukannya pemeriksaan fisik di Tempat Penimbunan Sementara.

2. Fasilitas perpajakan dan kepabeanan memungkinkan PDKB dapat menciptakan harga yang kompetitif di pasar global serta dapat melakukan penghematan biaya perpajakan.

3. Cash flow perusahaan serta production schedule lebih terjamin. Membantu usaha pemerintah dalam rangka mengembangkan program antara keterkaitan antara perusahaan besar, menengah, dan kecil melalui pola kegiatan sub kontrak

\section{KESIMPULAN}

Kesimpulan dalam penelitian ini adalah:

1. penerapan kebijakan dan pemberian fasilitas kepabeanan oleh Direktorat Jenderal Bea dan Cukai memperlancar arus dokumen dan barang impor atau ekspor kepada pengusaha, sehingga pengusaha dapat menjalankan usahanya tanpa hambatan dan memperlancar cash

flow dari perusahaan.

2. Fasilitas yang diberikan KKPBC kepada kawasan berikat adalah: 1) Penangguhan Bea Masuk; 2) Pembebasan Cukai; 3) Pajak Dalam Rangka Impor (PPN, PPh 22, PPnBM).

\section{SARAN}

Saran yang bisa diberikan berdasarkan hasil penelitian antara lain:

1. Sebaiknya dalam pemeriksaan persyaratan administrasi harus diperketat kepada pengusaha yang ingin menjalankan perusahaannya di kawasan berikat supaya tidak terjadi pelanggaran persyaratan administrasi yang menyebabkan kerugian.

2. Menambah fasilitas mengenai batas waktu pengembalian barang dan/atau bahan yang dikeluarkan sementara ke tempat lain dalam daerah pabean untuk dikembalikan ke kawasan berikat.

3. Sebaiknya untuk penelitian berikutnya menambah variabel penelitian selain yang sudah diteliti.

\section{Daftar Pustaka}

Nugroho, Prasetyo Dwi. (2018). Pengaruh Orientasi Pasar dan Penghindaran Pajak terhadap Penyalahgunaan Fasilitas Pajak oleh Pengusaha Dalam Kawasan Berikat (PDKB) yang Terdaftar di Kantor Pengawasan dan Pelayanan Bea dan Cukai (KPPBC) Tipe Madya Pabean. Diambil dari: http://repository.president.ac.id/handle /123456789/564.

Peraturan DJBC Nomor PER 19/BC/2018 tentang perubahan atas DJBC PER 17/BC/2012 tentang Tata Laksana Kawasan Berikat.

Peraturan Menteri Keuangan Nomor 131/PMK.04/2018 tentang perubahan atas MenKeu No. 120/PMK.04/2013 tentang Kawasan Berikat.

Peraturan Pemerintah No. 85 Tahun 2015 tentang perubahan atas PP No. 32 Tahun 2009 tentang Tempat Penimbunan Berikat.

Purwito, M Ali. (2006). Kepabeanan Konsep dan Aplikasi. Jakarta: Samudra Ilmu.

Purwito, M Ali. (2013). Kepabeanan Indonesia. Tangerang Selatan: Jelajah Nusa. 
Risnanda, Olgi. (2019). Prosedur Pengeluaran Barang impor terhadapPenangguhan Bea Masuk melalui Kawasan Berikat di Kantor Pengawasandan Pelayanan Bea Cukai (KPPBC) Tipe Madya Pabean B Pekanbaru. Diambil dari: http://repository.uinsuska.ac.id/24896/

Undang-undang No. 42 Tahun 2000. "Pajak Pertanbahan Nilai Barang Dan Jasa Dan Pajak Penjualan Atas Barang Mewah".Diambil dari: https://www.pajak.go.id/id/undangundang-nomor-42-tahun2009\#: :text=Menetapkan\%3A,PAJA K\%20PENJUALAN\%20ATAS\%20B ARANG\%20MEWAH. (20/04/2021,11:31)

Valentina, Deby. (2019). Analisis Pengawasan Serta Pengaruh Kawasan Berikat Terhadap Arus Kas, Beban Pajak Dan Aktivitas Ekspor Pt.Xyz. Jurnal Manajemen Bisnis dan Kewirausahaan, Vol.3 no.3 2019.

Widyastuti, I., \& Sahara, A. (2018). Analisa Sistem Informasi Akuntansi Pembelian Bahan Baku Impor Pada Kawasan Berikat. 5(2), 8-10. Retrieved from http://ejournal.bsi.ac.id/ejurnal/index.p $\mathrm{hp} / \mathrm{moneter/article/view/4495}$

Yunita, Ratna. (2013). Analisis Pengawasan Kebijakan Fasilitas Kawasan Berikat Bagi Importir Produsen Pada Kawasan Berikat. 